\title{
Application of secondary nutrients and micronutrients increases crop yields in sub-Saharan Africa
}

\author{
Job Kihara ${ }^{1}$ (D) Gudeta Weldesemayat Sileshi $^{2} \cdot$ Generose Nziguheba $^{3}$. \\ Michael Kinyua ${ }^{4}$ - Shamie Zingore ${ }^{5}$ - Rolf Sommer ${ }^{1}$
}

Accepted: 1 June 2017 / Published online: 3 July 2017

(C) The Author(s) 2017. This article is an open access publication

\begin{abstract}
Secondary and micronutrients are important in enhancing crop productivity; yet, they are hardly studied in subSahara Africa. In this region, the main focus has been on macronutrients but there is emerging though scattered evidence of crop productivity limitations by the secondary and micronutrients. Elsewhere, widespread deficiencies of these nutrients are associated with stagnation of yields. Here, we undertake a meta-analysis using 40 articles reporting crop response to secondary and micronutrients to (1) determine the productivity increase of crops and nutrient use efficiency associated with these nutrients, and (2) provide synthesis of responses to secondary nutrients and micronutrients in subSahara Africa. This study used 757 yield data rows (530 from publications and 227 from Africa Soil Information Service) from field trials carried out in SSA between 1969 and 2013 in 14 countries. Data from publications constituted response to $\mathrm{S}$ (49.4\%), Zn (23.0\%), S and micronutrient combinations $(11.5 \%)$, and $<10 \%$ each for $\mathrm{Cu}, \mathrm{Mo}, \mathrm{Fe}$, and B. Data from
\end{abstract}

Job Kihara

j.kihara@cgiar.org

1 International Center for Tropical Agriculture (CIAT) c/o ICIPE Duduville Complex, Off Kasarani Road, PO Box 823-00621, Nairobi, Kenya

2 Plot 1244 Ibex Hill, Lusaka, Zambia

3 International Institute of Tropical Agriculture (IITA) c/o ICIPE Duduville Complex, Off Kasarani Road, PO Box 823-00621, Nairobi, Kenya

4 School of Environmental Studies, Kenyatta University, P.O. Box 43844-00100, Nairobi, Kenya

5 International Plant Nutrition Institute, Sub-Saharan Africa Program, IFDC_-East and Southern Africa Division, ICIPE Complex, Duduville-Kasarani, Thika Road, P.O. Box 30772-00100, Nairobi, Kenya
Africa Soil Information Service were all for S and micronutrient combinations. Of the two sources, most yield data are for maize $(73.6 \%)$, followed by sorghum $(6.7 \%)$ and wheat $(6.1 \%)$ while rice, cowpea, faba bean, tef, and soybean each accounted for less than 5\%. The major points are the following: (1) application of $\mathrm{S}$ and micronutrients increased maize yield by $0.84 \mathrm{t} \mathrm{ha}^{-1}$ (i.e., $25 \%$ ) over macronutrient only treatment and achieved agronomic efficiencies (kilograms of grain increase per kilogram of micronutrient added) between 38 and 432 and (2) response ratios were $>1$ for $S$ and all micronutrients, i.e., the probability of response ratio exceeding 1 was 0.77 for $\mathrm{S}$ and 0.83 for $\mathrm{Zn}, 0.95$ for $\mathrm{Cu}$, and 0.92 for $\mathrm{Fe}$, and indicates positive crop response for a majority of farmers. We conclude that $\mathrm{S}$ and micronutrients are holding back crop productivity especially on soils where response to macronutrients is low and that more research is needed to unravel conditions under which application of $\mathrm{S}$ and micronutrients may pose financial risks.

Keywords Agronomic efficiency · Boundary analysis · Meta-analysis $\cdot$ Sulfur $\cdot$ Effect size $\cdot$ Response ratio

\section{Contents}

1. Introduction

2. Materials and methods

\subsection{Choice of crops}

2.2 Data retrieval

2.3 Data analysis

3. Results and discussion

3.1 Overall crop yield response

3.2 Agronomic efficiency

4. Conclusions

5. References

6. Acknowledgements 


\section{Introduction}

For the last three decades, crop nutrition research in subSaharan Africa (SSA) has largely focused on macronutrients, i.e., nitrogen, phosphorus, and potassium (Chilimba and Chirwa 2000; Stoorvogel et al. 1993; Voortman 2012; Vanlauwe et al. 2015). However, there are strong indications from some studies of the effects of deficiencies in secondary nutrients and micronutrients limiting crop productivity in SSA, especially under continuous cropping without nutrient replenishment (Vanlauwe et al. 2015; Van Asten et al. 2004; Fig. 1). For example, low productive spots related to zinc $(\mathrm{Zn})$ deficiency have been observed in rice (Van Asten et al. 2004) following continuous cultivation without micronutrient application, but could also relate to interactions with other factors such as soil alkalinity and high plant available soil P. In Ethiopia, Rwanda, and Burundi, sulfur (S), Zn, and boron (B) are deficient in large proportions of arable land (Vanlauwe et al. 2015). In other words, nutrients other than the macronutrients are becoming important limitations in crop production in SSA. Deficiencies of secondary nutrients and micronutrients have also been observed in other parts of the world such as Campo Cerrado soils of Brazil, Ilanos of Colombia, and calcareous soils of Pakistan, India, and the Philippines (Lopes 1980; Ryan et al. 2013). Stagnation of yields some 10 years ago in India was primarily because of widespread deficiencies of these important secondary and micronutrients, mainly S, B, and $\mathrm{Zn}$ (Sahrawat et al. 2010). In comparison to other regions of the world, relatively little research has been done on secondary and micronutrient deficiencies in soils and the corresponding crop responses in SSA.

The lack of sufficient focus on micronutrients and the related crop response in SSA have been echoed by experts in different generations (Lopes 1980; Kang and Osiname 1985; Weil and Mughogho 1999; Gungula and Garjila 2006). As early as the 1970s, molybdenum (Mo), $\mathrm{Zn}$, and $\mathrm{B}$ were identified as the most important micronutrients but only for selected crops such as cotton and groundnuts mainly in areas under intensification (Drosdoff 1972). Apart from such areas of intensification, long fallow periods under the then shifting cultivation replenished sufficient macro-, secondary, and micronutrients, making it unlikely to experience deficiencies within that traditional agricultural system. In the review by Lopes (1980), only a few micronutrient (Mn, $\mathrm{Zn}, \mathrm{B}, \mathrm{Fe}$, and $\mathrm{Mo}$ ) studies in sub-Sahara Africa are mentioned and, similarly to Drosdoff (1972), none of the studies included cereals (maize, wheat, rice, sorghum, or millet) under field conditions. A decade later, Sillanpaa (1982), in a global study involving 30 countries, identified micronutrient deficiencies in for two

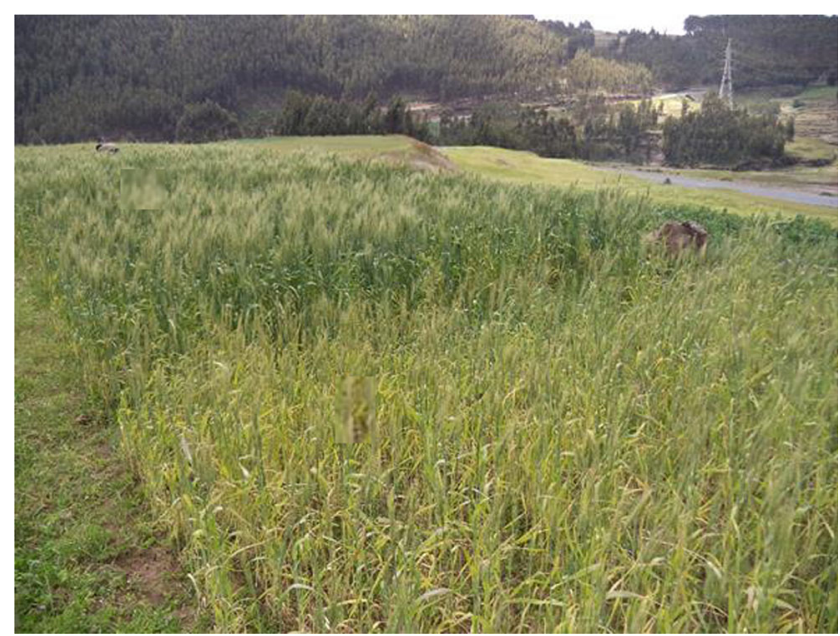

Fig. 1 Experimental field showing a control treatment (foreground) and a fertilizer treatment including sulfur and micronutrients in Ethiopia in 2014

cereals (maize and wheat) in Ethiopia, Ghana, Malawi, Nigeria, Sierra Leone, Tanzania, and Zambia, and highlighted the need for micronutrient supply especially copper $(\mathrm{Cu}), \mathrm{B}, \mathrm{Zn}$, and Mo to address observed deficiencies and to realize full potential in agriculture productivity in developing countries.

Recently, Kihara and Njoroge (2013) noted that maximum maize grain yield obtained in fields under researcher management in western Kenya, a region with potential yield of at least $10 \mathrm{t} \mathrm{ha}^{-1}$, stagnated at $7 \mathrm{tha}^{-1}$. This is likely to be the result of deficiencies in secondary and micronutrients during crop growth, or the effect of low soil $\mathrm{pH}$ and associated toxicities (e.g., aluminum). Indeed, in the last decade, there has been growing evidence from the region of soils that barely responds to application of the commonly emphasized macronutrient-based fertilizers under smallholder farming (Tittonnell and Giller 2013), and researchers note that this is likely due to deficiencies of the secondary and micronutrients (Vanlauwe et al. 2015). Although there are increasing calls to include secondary and micronutrients in fertilizers in SSA (Chianu et al. 2012), the limited and scattered research on potential responses to these nutrients has not been reviewed to understand their contribution to crop productivity. The aim of this study was to determine the productivity increase in cereal and grain legume crops and nutrient use efficiency associated with application of secondary and micronutrients through a meta-analysis of available published data, and to provide synthesis of responses to secondary nutrients and micronutrients in SSA. We aimed to answer the specific research question: "What is the magnitude of change in yield due to application of $\mathrm{S}$ and micronutrients applied alone or in combination?" 


\section{Materials and methods}

\subsection{Choice of crops}

This meta-analysis focused on maize, rice, wheat, sorghum, cowpea, and soybean because of data availability and the importance of these crops in SSA. Maize is the key focus of most studies on crop response to $\mathrm{S}$ and micronutrients in SSA with a limited number of studies on wheat, rice, cowpea, sorghum, and soybean responses. Maize, constituting $45 \%$ of the cereal production in SSA in 2014, is the staple food crop (accounting for over $40 \%$ of the calories consumed in some countries such as Malawi and Zambia (http://www.fao.org/faostat/en/\#data)) and the main component of food aid interventions in SSA (Leonardo et al. 2015). It is also grown under widely varying climatic, soil, and altitudinal conditions ranging from sea level (the coastal zones) to elevations above $2400 \mathrm{~m}$ (Sileshi et al. 2010). Rice, the most rapidly growing food source in Africa, is a strategic crop and a staple food in many countries (Wopereis et al. 2013). Sorghum accounted for $16 \%$ of all cereal production in Africa in 2014. Wheat is also an important staple crop whose consumption steadily increased during the past 20 years as a result of growing population, changing food preferences, and socioeconomic transformations associated with urbanization. It constituted $14 \%$ of all cereal production in Africa in 2014 (FAOSTAT). Soybean is an important pulse, currently widely promoted for its high protein content and superior biological nitrogen fixation (Adesoji et al. 2009). Like soybean, cowpea is an important source of proteins especially for poor rural families in dry sub-humid and semi-arid zones of SSA (Gungula and Garjila 2006).

\subsection{Data retrieval}

This study used data from field trials carried out in SSA between 1969 and 2013. The data were derived from 40 peerreviewed publications accessed online (Table 1). Basically, on 24 November 2016, advanced search was made in the Web of Knowledge using the equation: $\mathrm{TS}=$ (micronutrient* AND crop yield AND Africa) OR TS=(sulfur AND crop yield AND Africa) OR TS=(sulphur AND crop yield AND Africa) OR TS=(boron AND crop yield AND Africa) OR $\mathrm{TS}=$ (zinc AND crop yield AND Africa) $\mathrm{OR} T \mathrm{TS}=$ (manganese AND crop yield AND Africa) OR TS=(molyb*AND crop yield AND Africa) OR TS=(copper AND crop yield AND Africa) $\mathrm{OR} T S=$ (calcium AND crop yield AND Africa) OR $\mathrm{TS}=($ magnesium AND crop yield AND Africa) $\mathrm{OR} T \mathrm{TS}=($ iron AND crop yield AND Africa), where OR and AND are boolean operators and TS=topic. Although time span was set to all years, it only returned articles published between 2005 and 2016. As such, we also used the Google Scholar literature search engine where search for the keywords micronutrients, sulfur, zinc, boron, crop response, and sub-Sahara Africa in multiple combinations was undertaken. Also, search was made for titles of publications in reference lists of journal articles referring to micronutrient use. A study was included if it was conducted in SSA and met three conditions as follows: (i) included maize, sorghum, rice, tef, cowpea, soybean, faba bean, or wheat as test crops; (ii) included both a treatment with macronutrients only (fertilized control) and a similarly managed treatment but with $\mathrm{S}$ and/or micronutrients in addition to the macronutrients in the fertilized control treatment (i.e., same rate of macronutrients in both control and test); and,(iii) reported yield data for treatments under condition ii. Crop response to $\mathrm{Ca}$ and $\mathrm{Mg}$ is not commonly investigated and therefore has not been considered here. Data for absolute control treatments (i.e., unfertilized) were also obtained, although these were not available in all studies. Pot and greenhouse experiments, and studies where yields were reported in units per plant without providing data on plant population, as well as publications that reported yields as percentages were excluded as these lacked true productivity information. In some cases, the source of P (e.g., SSP) and sources of micronutrients (e.g., ZnS) contained S. As such, we assumed that if the $\mathrm{S}$ contained in the macronutrient control treatment was at least $40 \mathrm{~kg} \mathrm{~S} \mathrm{ha}^{-1}$, further $\mathrm{S}$ in the micronutrient treatment can be ignored since no further response to $\mathrm{S}$ is expected (Kang and Osiname 1976; Ojeniyi and Kayode 1993). When no $\mathrm{S}$ was included in the macronutrient control treatment, but the micronutrient source also contained S (e.g., in the form of zinc sulfate, in the case of Abbas et al. (2007)), we considered this as "combined" rather than single micronutrient response.

In total 530 rows of yield data were extracted from the 40 papers of which $49.4 \%$ were on $\mathrm{S}$ response, $23.0 \%$ on $\mathrm{Zn}$, $7.4 \%$ on $\mathrm{Cu}, 3.0 \%$ on $\mathrm{Mo}, 4.5 \%$ on $\mathrm{Fe}, 1.1 \%$ on $\mathrm{B}$, and $11.5 \%$ involved two or more, i.e., $\mathrm{S}$ and micronutrient combinations. These data are from 14 countries namely Nigeria (36.6\%), Malawi (12.8\%), Ethiopia (21.8\%), Kenya (3.4\%), Côte d'Ivoire (3.0\%), Ghana (4.3\%), Zambia (3.0\%), Sudan (2.3\%), Zimbabwe (2.3), Togo (6.0\%), Mozambique (1.5\%), Tanzania (1.3\%), Benin (1.1\%), and Burkina Faso (0.4\%). The data were derived from both on- farm and on-station trials under researcher management. All the data obtained are on improved crop varieties except for wheat where 18 of the 46 data rows used local wheat variety in Ethiopia. From all the publications, data on soil types were obtained; if presented otherwise, the information was obtained from ISRIC maps based on locational information presented in the publications. The studies cover most soil types prevalent in SSA namely Acrisols, Cambisols, Ferralsols, Fluvisols, Gleysols, Leptosols, Lixisols, Luvisols, Nitisols, Plinthosols, and Vertisols. The sites also represent different climates with mean annual rainfall from 255 to $2860 \mathrm{~mm}$. The intensity of research on micronutrient responses varied with time, and $19.2 \%$ of the studies were conducted in 1969-1980, $15.8 \%$ in $1981-1990,7.9 \%$ in $1991-2000,48.1 \%$ in $2000-2010$, and 
Table 1 List of publications, the study locations within sub-Saharan Africa, and secondary and micronutrients used in this study of crop responses

\begin{tabular}{|c|c|c|c|c|}
\hline Authors & Source & Country of study & $\begin{array}{l}\text { Yield data } \\
\text { rows }\end{array}$ & Nutrient of focus \\
\hline Abbas et al. 2007 & Gezira J. of Agri Sci 5 (2) & Sudan & 12 & $\mathrm{Zn}$ \\
\hline $\begin{array}{l}\text { Abunyewa and Mercer-Quarshie } \\
2004\end{array}$ & Asian J. of Plant Sci 3 (1): 1-5 & Ghana & 12 & $\mathrm{Zn}$ \\
\hline Adesoji et al. 2009 & American-Eurasian J. of Sus Agri, 3(4): 845-849 & Nigeria & 6 & Mo \\
\hline Admas et al. 2015 & & & 18 & \\
\hline Afolabi et al. 2014 & Int. J. of Agri \& Rural Dev. 17(3): 2006-2011 & Nigeria & 4 & $\begin{array}{l}\text { B, Mo, } \mathrm{Zn}, \\
\text { combination }\end{array}$ \\
\hline AfSIS & & & 227 & \\
\hline Allan 1970 & FAO Soils Bulletin 14 & Kenya & 18 & $\mathrm{~S}$ \\
\hline Chaguala et al. 2011 & Afr Crop Sci Proc. 10: 611-615 & Mozambique & 8 & $\mathrm{~S}$ \\
\hline Chiezey 2014 & J. of Agri Sci. 6(3);2014 & Nigeria & 9 & $\mathrm{Zn}$ \\
\hline Chilimba and Chirwa 2000 & $\begin{array}{l}\text { Sulfur Nutr Def Amendment for Maize Pro in } \\
\text { Malawi }\end{array}$ & Malawi & 48 & $\mathrm{~S}$ \\
\hline Chude et al. 2003 & $\begin{array}{l}\text { Badu-Apraku B, Fakorede MAB, Ouedraogo M, } \\
\text { Carsky } \\
\text { RJ, Menkir A. (eds) (2003) p 201-207 }\end{array}$ & Nigeria & 4 & $\mathrm{Zn}$ \\
\hline Desta et al. 2015 & J Soil Sci Environ Manag (2015) 6:9-15 & Ethiopia & 12 & $\mathrm{Zn}$ \\
\hline Desta 2015 & Int J Recent Sci Res (2015) 6: 5689-5698 & Ethiopia & 8 & $\mathrm{~S}$ \\
\hline Eteng et al. 2014 & Open J. of Soil Sci, 4: 235-245 & Nigeria & 12 & $\mathrm{Cu}, \mathrm{Zn}$ \\
\hline Florent et al. 2014 & J. of Advances in Agri 3(1): 129-141 & Côte d'Ivoire & 9 & Zn, combination \\
\hline Friesen 1991 & $\begin{array}{l}\text { Mokwunye AU (Ed.) (1991) Kluwer Academic } \\
\text { Publishers p 59-68 }\end{array}$ & $\begin{array}{l}\text { Niger, Burkina Faso, } \\
\text { Togo }\end{array}$ & 20 & $\mathrm{~S}$ \\
\hline Gungula and Garjila 2006 & $\begin{array}{l}\text { American-Eurasian J. of Agri \& Envi Sci, 1(2): } \\
\text { 96-101 }\end{array}$ & Nigeria & 3 & Mo \\
\hline Habtegebrial and Singh 2006 & Nutr Cycl Agroecosyst (2006) 75:213-222 & Ethiopia & 24 & $\mathrm{~S}$ \\
\hline Habtegebrial and Singh 2009 & J. of Plant Nutr, 32(10): 1768-1787 & Ethiopia & 36 & $\mathrm{~S}$ \\
\hline Habtegebrial et al. 2013 & J. of Soil Sci and Mgt 4(3): 62-70 & Ethiopia & 10 & $\mathrm{~S}$ \\
\hline Habtemichial et al. 2007 & J. Plant Nutr Soil Sci (2007) 170, 412-418 & Ethiopia & 6 & $\mathrm{~S}$ \\
\hline Haileselasssie et al. 2011 & Soil Sci \& Plant Nutr, 57(4): 587-596 & Ethiopia & 1 & Combined \\
\hline Kang and Osiname 1976 & Agro J., 68: 333-336 & Nigeria & 24 & $\mathrm{~S}$ \\
\hline Kayode 1984 & Expl Agric (1984) 20: 335-337 & Nigeria & 16 & $\mathrm{Fe}$ \\
\hline Kayode and Agboola 1985 & Fert Res 8:129-135 & Nigeria & 36 & $\begin{array}{l}\mathrm{Cu}, \mathrm{Fe}, \mathrm{Zn} \\
\quad \text { combination }\end{array}$ \\
\hline Kone et al. 2011 & Archives of Agro Soil Sci (2011) 57(7): 763-774 & Benin & 6 & $\mathrm{Zn}$ \\
\hline Kone et al. 2014 & Archives of Agron Soil Sci (2014) 60: 735-746 & Côte d'Ivoire & 3 & $\mathrm{Zn}$ \\
\hline Kurwakumire et al. 2015 & Agron J (2015) 107: 1068-1076 & Zimbabwe & 6 & Combination \\
\hline Lisuma et al. 2006 & J. of Soil \& Crop Manag, 98:402-406 & Tanzania & 7 & $\begin{array}{l}\mathrm{B}, \mathrm{Cu}, \mathrm{Zn}, \\
\quad \text { combination }\end{array}$ \\
\hline Manzeke et al. 2014 & Field Crops Res 166 (2014) 128-136 & Zimbabwe & 6 & $\mathrm{Zn}$ \\
\hline Nesgea et al. 2012 & Int.J. Agr \& Res, 2(9): 14-32 & Ethiopia & 1 & $\mathrm{~S}$ \\
\hline Nyalemegbe et al. 2011 & Int. Res J. of Agri Sci \& Soil Sci, 2(1): 008-016 & Ghana & 5 & $\mathrm{~S}$ \\
\hline Nziguheba et al. 2009 & Plant \& Soil DOI 10.1007/s11104-008-9714-1 & Togo & 12 & $\mathrm{~B}, \mathrm{~S}, \mathrm{Zn}$ \\
\hline Ojeniyi and Kayode 1993 & J. of Agr Sci, Cambridge 120: 295-299 & Nigeria & 40 & $\mathrm{Cu}, \mathrm{S}$ \\
\hline Olivier et al. 2014 & Ind. J. Sci. Res.\& Tech. 2(2): 18-24 & Côte d'Ivoire & 3 & $\mathrm{Zn}$ \\
\hline Oseni 2009 & World J. of Agr Sci. 5(6): 670-674 & Nigeria & 16 & $\mathrm{Zn}$ \\
\hline Osiname et al. 1973 & Agron J (1973) 65: 875-877 & Nigeria & 24 & $\mathrm{Zn}$ \\
\hline Rechiatu et al. 2015 & J Plant Sci (2015) 3: 64-70 & Ghana & 6 & Mo \\
\hline Van Asten et al. 2004 & Land Degrad. Dev. 15: 383-396 & Burkina Faso & 2 & $\mathrm{Zn}$ \\
\hline Weil and Mughogho 1999 & Agro J. 92: 649-656 & Malawi & 20 & $\mathrm{~S}$ \\
\hline Yerokun and Chirwa 2014 & Afr J. of Agr Res 9(11): 963-970 & Zambia & 16 & $\mathrm{Zn}$ \\
\hline
\end{tabular}


$8.9 \%$ in $2010-2016$. The proportions of yield data per individual crop species reported from the various studies varied greatly with maize having the highest $(70 \%)$, followed by wheat $(8.7 \%)$ and rice $(6.6 \%)$. Cowpea, tef, faba bean, sorghum, and soybean each accounted for less than $3 \%$ of the yield data. None of the studies reported using organic resources as a nutrient management strategy.

In addition to the review, we include a dataset from multilocational trials implemented within the framework of Africa Soil Information System (AfSIS) and that provides a unique opportunity to relate response to soil micronutrients. The dataset consist of 227 data rows with response to combined secondary and micronutrients namely $\mathrm{Ca}, \mathrm{Mg}, \mathrm{S}, \mathrm{Zn}$, and B (implemented as one treatment). This is the only large and consistent dataset that provides observed yield with actual soil analysis. The data are from diagnostic trials implemented in Kenya, Malawi, Mali, Nigeria, and Tanzania and conducted for 1-2 seasons; the test crop was maize except in Mali where sorghum was used. The macronutrient control treatment had $100 \mathrm{~kg} \mathrm{~N} \mathrm{ha}^{-1}, 30 \mathrm{~kg} \mathrm{P} \mathrm{ha}^{-1}$, and $60 \mathrm{~kg} \mathrm{~K} \mathrm{ha}^{-1}$ for maize and $60 \mathrm{~kg} \mathrm{~N} \mathrm{ha}^{-1}, 20 \mathrm{~kg} \mathrm{P} \mathrm{ha}^{-1}$, and $30 \mathrm{~kg} \mathrm{~K} \mathrm{ha}^{-1}$ for sorghum. The sources of N, P, and K were urea, triple super phosphate, and muriate of potash, respectively. Secondary and micronutrients in the response treatment were applied at $10 \mathrm{~kg} \mathrm{Ca} \mathrm{ha}{ }^{-1}, 5 \mathrm{~kg} \mathrm{Mg} \mathrm{ha}^{-1}, 5 \mathrm{~kg} \mathrm{~S}^{-1}, 3 \mathrm{~kg} \mathrm{Zn} \mathrm{ha}^{-1}$, and trace amounts of $\mathrm{B}$. These were from a blended basal fertilizer, Mavuno. Detailed description of the implementation methods for these trials is reported by Huising et al. (2013) and is also accessible online (http://afsis-dt.ciat.cgiar.org) and from Kihara et al. (2016).

\subsection{Data analysis}

Data analysis, as also data retrieval, considered the six quality criteria of meta-analysis recommendations of Philibert et al. (2012). Most of the analysis involved a linear mixed modelling (LMM) approach implemented in the R statistical software (www.r-project.org). LMM was chosen, because the data gathered across studies were unbalanced with respect to sample sizes and treatments.

Initially, yield data following $\mathrm{S}$ and micronutrient application were plotted against the fertilized control yield in a scatter to demonstrate the distribution of crop response to applied nutrients. Also, means and the confidence limit of maize, wheat, and rice grain yield for the absolute control, the fertilized control (i.e., the macronutrient treatment), and the $\mathrm{S}$ and micronutrient treatment were obtained from the raw data. For this, bootstrap confidence limit was obtained using boot $\mathrm{R}$ package with 100 replications. Yield data for the absolute control were not available in some cases: of the 530 cases of yield data, the absolute control was available in 232 cases which represented $80 \%$ of the cases for both rice and wheat and 39\% for maize but these were available for all AfSIS data.
In the subsequent analysis, the effects of the $\mathrm{S}$ and micronutrients on maize yield (crop with sufficient data points) were estimated using LMM of the form. Yield is a function of fertilizer treatment with experimental site as the random variable. Here, treatment refers to either individual or combined application of S and micronutrients. Control refers to the crop that received N, P, and/or K fertilizer. In the mixed model, the site was used as random effect and parameters were estimated via restricted maximum likelihood (REML). The obtained means were used to estimate percentage yield increase following application of $\mathrm{S}$ and micronutrients.

As the index of effect size, we used the response ratio (RR) calculated as the ratio of the yields from the treatment (i.e., $\mathrm{S}$ and/or micronutrient) to yields from the fertilized control (i.e., plots receiving only macronutrients). $R R$ is a measure of the proportionate change resulting from a treatment and expressed as a natural $\log$ for meta-analysis (Hedges et al. 1999). Absence of publication bias for this measure was confirmed using funnel plot (Fig. 2). Since our objective was to obtain the mean responses and their confidence limits, our analysis of response ratio is averaged over different sites and application rates. Effect sizes in meta-analyses are normally weighted by study precisions (Philibert et al. 2012), most commonly by inverse of study variance, or the sample size. Weighting is important, because it increases the precision of the mean effect estimate and the power of the tests and improves sampling distribution of the test statistics (Gurevitch and Hedges 1999). However, nearly all of the studies we found did not report any measure of variance, but the numbers of replications were available. Before analysis, RR was log transformed (lnRR) to ensure normality (Hedges et al. 1999). Then $\operatorname{lnRR}$ values were weighted by the number of replicates, so that studies based on larger sample sizes are given more weight

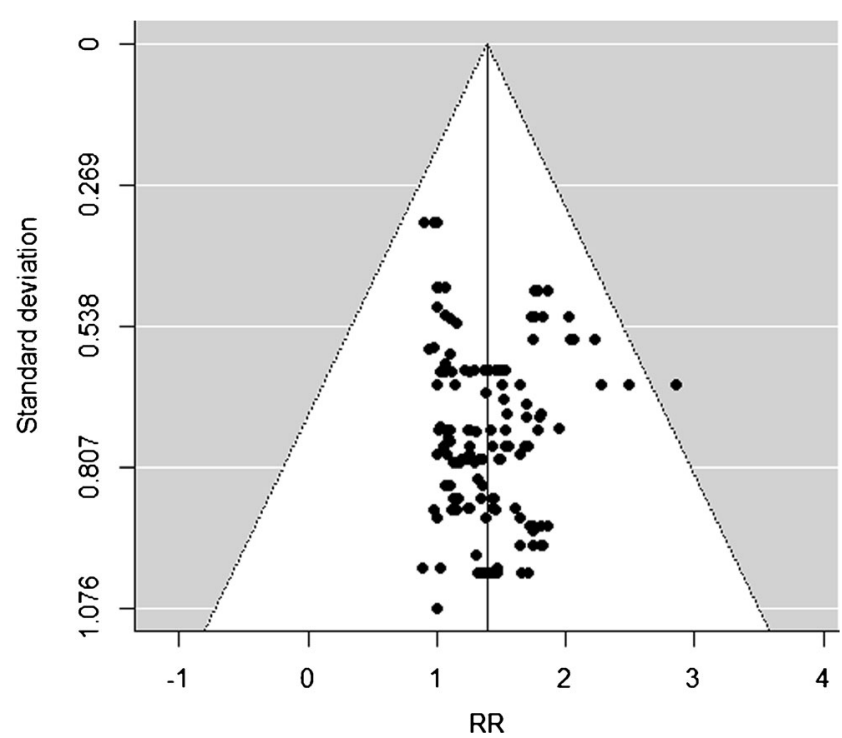

Fig. 2 Funnel plot of relationships between response ratio (RR) and standard deviations for the studies used 
than those based on small size. These values were subjected to LMM, and the means and 95\% confidence intervals for each study were computed via the REML method. These were then presented as forest plots (see also Hossard et al. (2016)).

Traditionally, inferences from meta-analyses are based on the mean and its $95 \%$ confidence interval. However, inference based on the mean alone can be misleading if the probability distribution of the response is not known (Sileshi et al. 2010). Therefore, we estimated the probability of obtaining a given response ratio. For this purpose, we generated the frequency distribution of response ratios and then calculated the cumulative probabilities. Then, we calculated the probability of exceeding a given level of response, for example, RR $>1,2$, etc., under application of a given nutrient.

We calculated the agronomic efficiency (AE $=$ kilograms of yield increase per kilogram of applied nutrient) of $S$ and micronutrients by maize as the difference between yield with fertilizer together with $\mathrm{S}$ or micronutrients and yield of the fertilized control and dividing by the quantity of applied $\mathrm{S}$ or micronutrient. $\mathrm{AE}$ is an integrated index of nutrient recovery efficiency and physiological or internal nutrient use efficiency (Ladha et al. 2005). Yield data where nutrients were applied in a combination were not included, because it was not possible to isolate agronomic efficiency associated with the individual nutrients. To establish the maximum AE that can be expected based on available data, boundary analysis (see also Kihara and Njoroge (2013)) was used on the three nutrients with a majority of yield data, namely $\mathrm{S}, \mathrm{Cu}$, and $\mathrm{Zn}$. Here, a boundary line was fit on the mean $\mathrm{AE}$ of the three highest points at every $10 \mathrm{~kg} \mathrm{ha}^{-1}$ for $\mathrm{S}$ and $1 \mathrm{~kg} \mathrm{ha}^{-1}$ intervals for $\mathrm{Cu}$ and $\mathrm{Zn}$ applied. These boundary lines are four-parameter log logistic curves fit using the dose response curve (drc) package in the $\mathrm{R}$ statistical software (www.r-project.org) that uses the formula:

$\mathrm{y}=f(x)=c+\frac{d-c}{1+\exp (b(\log (x)-\log (e)))}$

where,

$y \quad$ Agronomic efficiency (AE)

$x$ Amount of nutrient applied

$c$ Lower horizontal asymptote

d Upper horizontal asymptote

e Slope steepness

$b \quad \mathrm{ED}_{50}$ value

\section{Results and discussion}

\subsection{Overall crop yield response}

Maize, wheat, and rice showed positive yield responses to applied S or micronutrients (Fig. 3). In the case of sorghum, cowpea, and soybean, responses to $\mathrm{S}$ and micronutrients were low. For maize and wheat, responses to $\mathrm{S}$ and micronutrients decreased with increasing macronutrient control yields (Fig. 4). When all studies were combined (cross crops and sites), the overall effect size ( $R R=1.20 ; 95 \%$ CL 1.18 1.23) was significantly greater than unity (Fig. 5), indicating an overall positive crop response to $\mathrm{S}$ and micronutrients. In 19 out of the 41 studies, RR values were significantly larger than 1 , while in 18 studies, RR was not significantly different from 1. Only one study had an effect size significantly lower than 1, indicating significant reduction in yields due to application of S or micronutrients (Fig. 5a). The largest increase in response was noted in Burkina Faso (Fig. 5b).

The overall positive response to micronutrients indicates that these nutrients are holding back crop productivity, particularly in areas with low response to macronutrients, and that their application can have huge effect in some locations. Low crop productivity under macronutrient application in SSA has often been reported (Kihara and Njoroge 2013), and it has been suggested that deficiencies of secondary and micronutrients could be one of the causes to limited crop response to macronutrients (Vanlauwe et al. 2015). In the case of maize, application of $\mathrm{S}$ and micronutrients resulted in average $0.7 \mathrm{t} \mathrm{ha}^{-1}$ (i.e., $20 \%$ ) more yield compared to the macronutrient control treatment (Fig. 6). Similarly, wheat and rice yield were increased over macronutrient only treatment by 27 and $12 \%$, respectively, following additional application of S and micronutrients. Thus, although application of macronutrients resulted in $1.87 \mathrm{t} \mathrm{ha}^{-1}$ (i.e., 122\%) more maize, $0.85 \mathrm{t} \mathrm{ha}^{-1}$ (i.e., $41 \%$ ) more wheat, and $1.3 \mathrm{t} \mathrm{ha}^{-1}$ (i.e., $81 \%$ ) more rice grain yield increase over the unfertilized (no-input) treatment, application of $\mathrm{S}$ and micronutrients still led to an additional yield increase. Addressing such secondary and micronutrient deficiencies is critical to resolving the recurrent food insecurity challenge facing SSA that is heightened by burgeoning population and climate change. Understanding the conditions under which different responses occur and designing fertilizer solutions to address the limitations are critical in maintaining and or increasing crop productivity. The responses to $\mathrm{S}$ and micronutrients vary between crops, and it can be expected that variations in responses exist between crop varieties within a specific crop, though these may translate more in nutrient contents than in crop yields (De Valenca et al. 2017). The studies included in this paper are from researcher-managed trials, and improved crop varieties were used. Improved varieties have gained focus in initiatives to combat food insecurity, owing to their high yielding capacity. Given that crop response to fertilizers (macronutrients) has been shown for such improved varieties than for local varieties (Vanlauwe et al. 2011), it is important to understand the responses among varieties also in relation to $\mathrm{S}$ and micronutrients.

Overall, mean yield increment (over the mean of fertilized control and based on mixed models) realized by the 
Fig. 3 Effect of S and/or micronutrient application on yield of (a) maize, (b) wheat, (c) rice, (d) sorghum, (e) soybean and (f) cowpea across a range of control yields in SSA. The fertilized control was the crop that received the recommended rate of $\mathrm{N}, \mathrm{P}$, and $\mathrm{K}$ fertilizer. $\mathrm{N}$ represents the sample size

\section{Grain yield}

$\left(\mathrm{t} \mathrm{ha}^{-1}\right)$ of

micronutrient
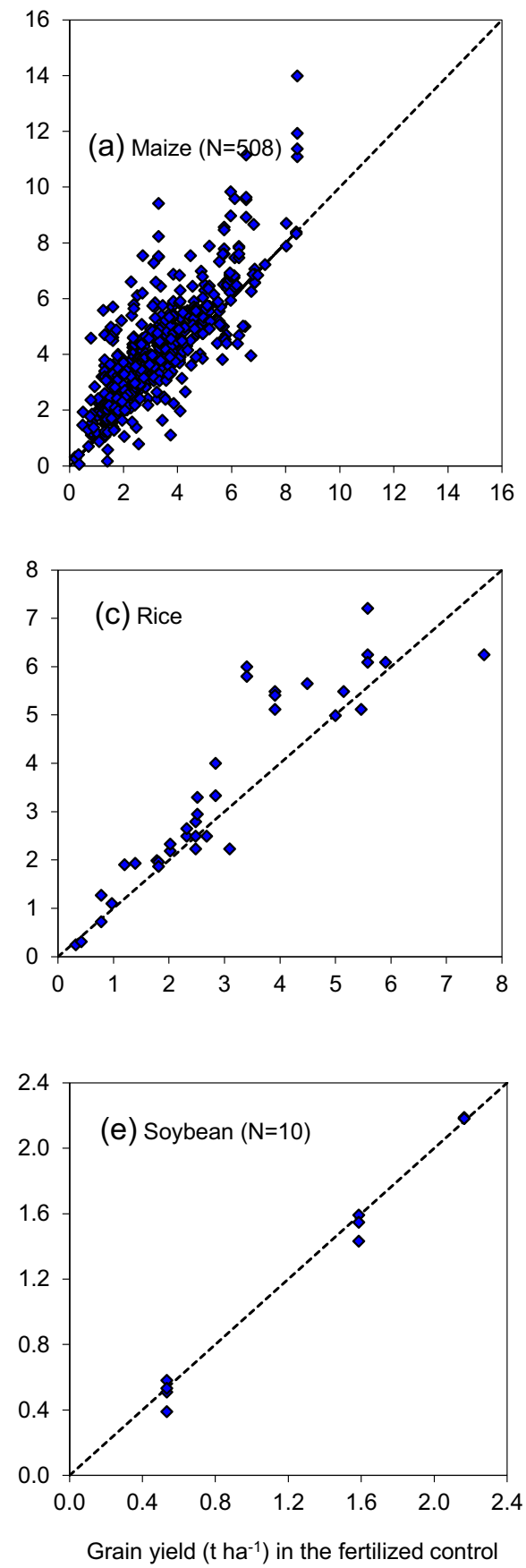

Grain yield

$\left(\mathrm{t} \mathrm{ha}{ }^{-1}\right)$ of

micronutrient
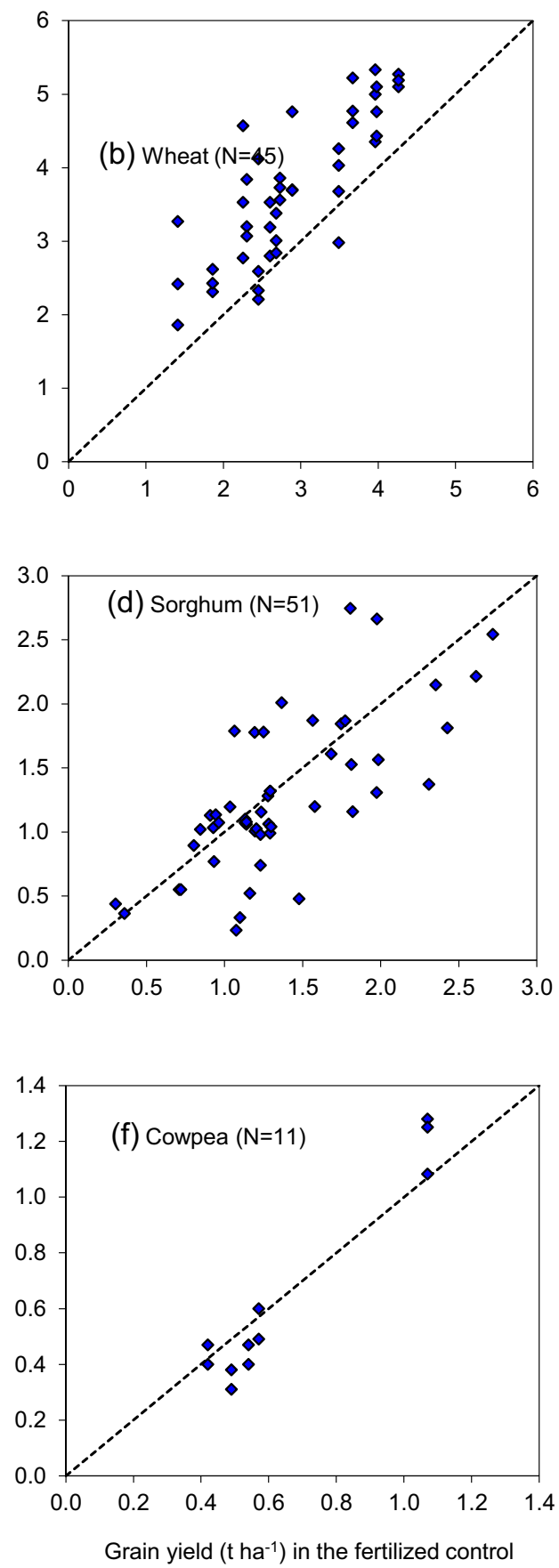

application of specific nutrients are $26 \%$ for S, $6 \%$ for B, $15 \%$ for $\mathrm{Zn}, 13 \%$ for $\mathrm{Cu}, 9 \%$ for $\mathrm{Fe}$, and $20 \%$ for combinations of $\mathrm{S}$ and micronutrients (see also Fig. 7). Several studies (Sillanpaa 1982; Van Asten et al. 2004; Oyinlola and Chude 2010) have reported deficiencies of one or more $\mathrm{S}$ and micronutrients in specific regions in Ivory Coast, Nigeria, Togo, Democratic Republic of the Congo, Kenya, Sudan, Ethiopia, Ghana, Malawi, Sierra Leone, Tanzania, Zambia, and Burkina Faso.
These deficiencies can be widespread as noted by Abe et al. (2010) for Zn and S deficiencies in the lowland soils of West Africa, by Chilimba and Chirwa (2000) for S in Malawi, and by Vanlauwe et al. (2015) for S, Zn, and B in Ethiopia. Buri et al. (2000) reported that over $66 \%$ of West Africa lowland soils had available $\mathrm{Zn}$ below the critical level of $0.8 \mathrm{mg} \mathrm{kg}^{-1}$. Although relative yield increase due to combined $\mathrm{S}$ and micronutrients is not different from single nutrients (e.g., $\mathrm{S}$ 


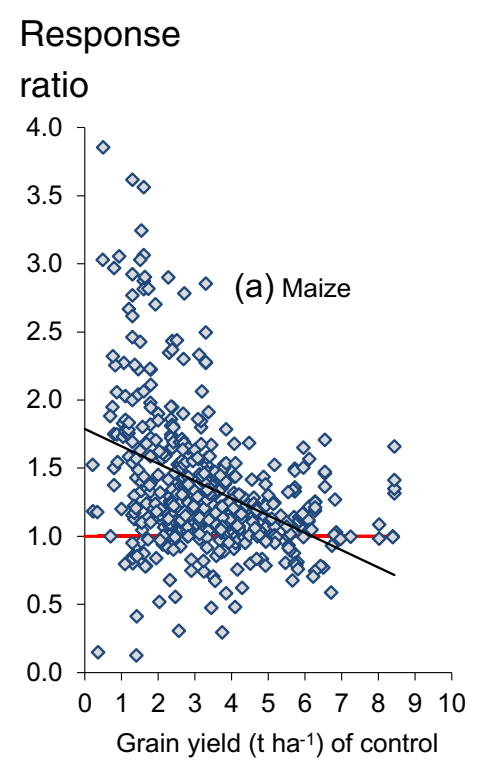

\section{Response}
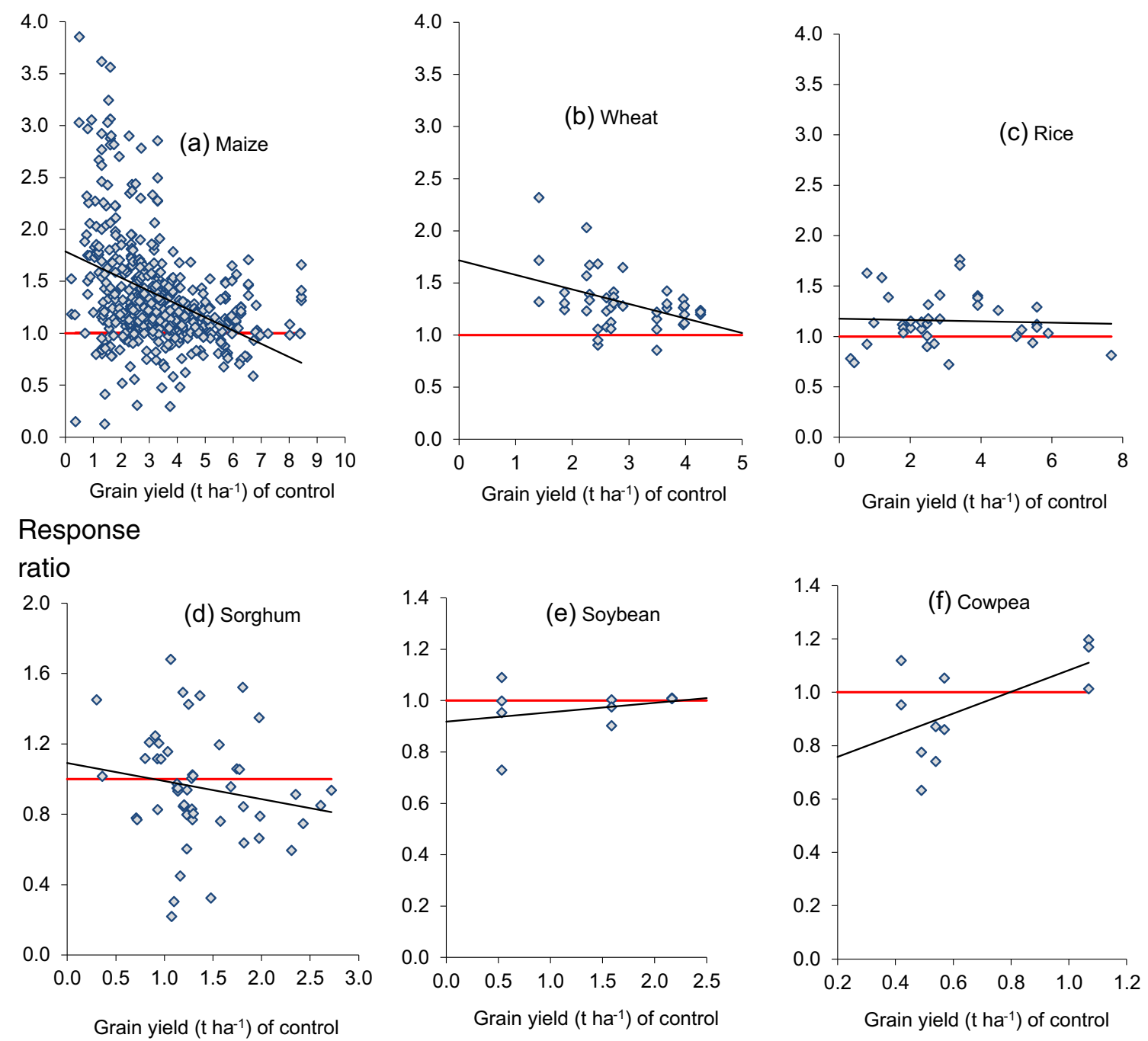

Fig. 4 Variations in response of (a) maize, (b) wheat, (c) rice, (d) sorghum, (e) soybean and (f) cowpea with the level of control yield. The red line represents $\mathrm{RR}=1$ while the black line represents the trend condition. The control is the plot that received macronutrients

and $\mathrm{Zn}$ ), arguments favoring combined rather than the single secondary and micronutrients applications have been made (Vanlauwe et al. 2015). On the other hand, some studies report sufficiency of $\mathrm{S}$ and micronutrients such as $\mathrm{Cu}, \mathrm{Fe}$, and $\mathrm{Zn}$ in Western Usambara Mountains of Lushoto in Tanzania (Ndakidemi and Semoka 2006); Zn and B in Gongola River Basin (Adeboye 2011); and Fe and Mn at Bauchi in Guinea Savanna, Samaru in northern Guinea, and Kadawa in Sudan Savanna (Oyinlola and Chude 2010). Also, Snapp (1998), in a study involving 1130 soil samples in Malawi, observed limited deficiencies in $\mathrm{Zn}$ with at least $90 \%$ of the cases having more $\mathrm{Zn}$ than the critical limit of $0.8 \mathrm{mg} \mathrm{Zn} \mathrm{kg}{ }^{-1}$. Thus, while combined $\mathrm{S}$ and micronutrients applications may be the best option in some cases, there is no need for applications of those nutrients available in soil in sufficient quantities as this can not only limit profitability and economic returns for farmers but also lead to toxic levels of some micronutrients if not well monitored. This highlights the need for identification of micronutrient limitations and recommending management that is focused on the specific nutritional problems in different regions/sites. Also, as crop production increases from the current low-input levels following green revolution initiatives, the deficiencies could become more significant and spread out (Current practices are low yielding and may not reveal crop growth limitations.).

Overall, estimates and $95 \%$ confidence limits of RR were 1.35 (1.28-1.41) for $\mathrm{S}, 1.54$ (1.35-1.74) for $\mathrm{Cu}, 1.34$ (1.231.44) for Fe, and 1.40 (1.29-1.51) for $\mathrm{Zn}$. The probability of RR exceeding 1 (i.e., yields increasing over the macronutrient control) was 0.77 for $\mathrm{S}$ and 0.83 for $\mathrm{Zn}$ (Fig. 8). The 
Fig. 5 Forest plot of the variation in effect sizes with study (a) and from country to country (b). Horizontal bars represent $95 \%$ confidence limits. The vertical bar in (b) represents RR $=1$ (i.e., no effect of micronutrients)
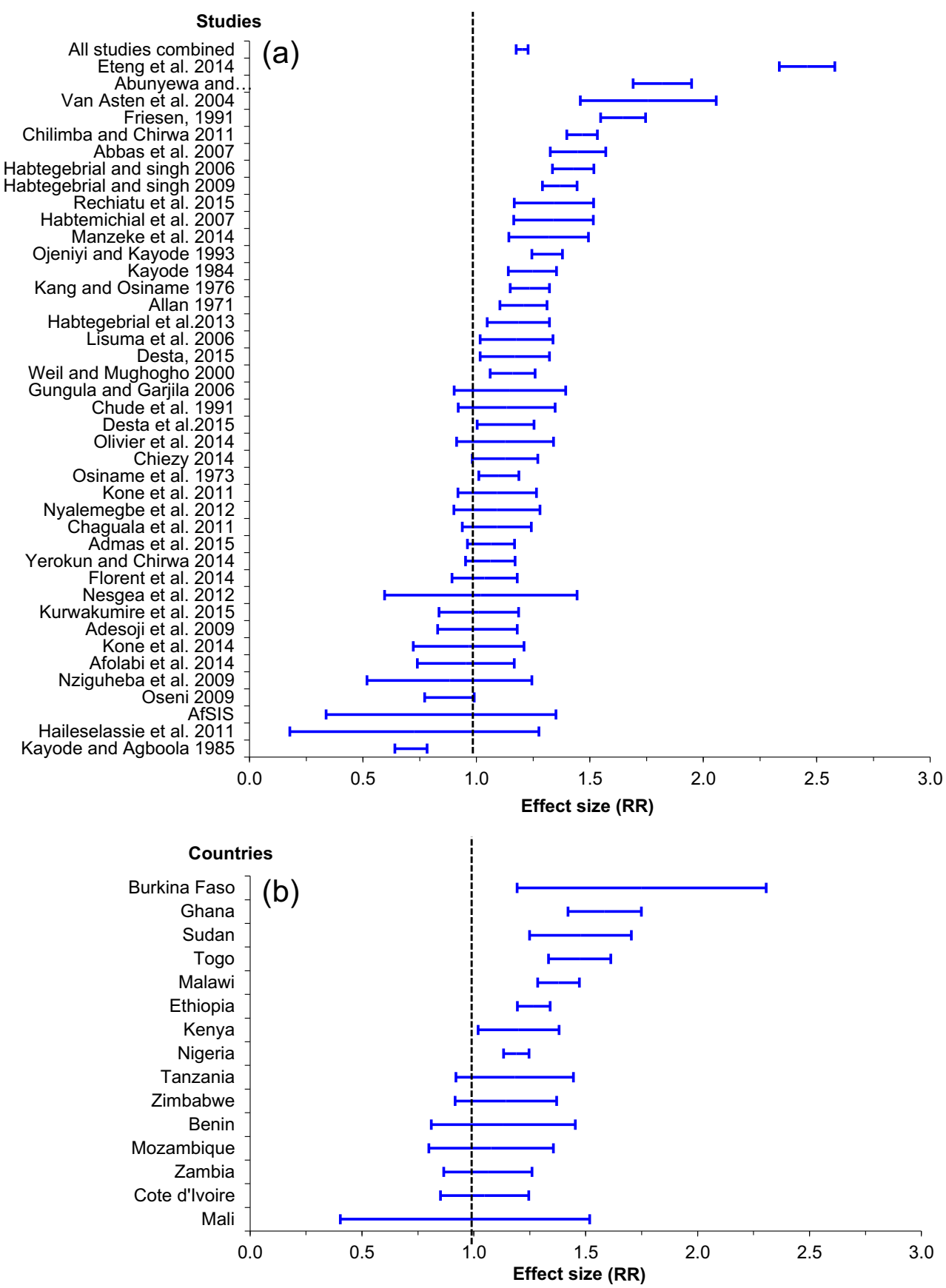

probabilities of RR exceeding 1 for $\mathrm{Cu}$ and $\mathrm{Fe}$ were 0.95 and 0.92 , respectively. In other words, $\mathrm{RR}<1$ that constitute risks to the farmer were very low for micronutrients. This highlights the fact that the benefits of applying macronutrients in combination with $\mathrm{S}$ and micronutrients far outweigh the risk to farmers. Ironically, only one of the 41 studies whose data are used in the current analysis, i.e., Van Asten et al. (2004), did an economic analysis of micronutrient used $(\mathrm{Zn})$ with results being highly profitable (value cost ratio $>2$ ). The lack of economic analysis in most of these studies translates a general gap of knowledge on the profitability of secondary and micronutrient fertilization in SSA. Indirect assumptions have often been made: for example, Weil and Mughogho (1999), in their work on $\mathrm{S}$ in four regions of Malawi, concluded that the 80 160-kg maize grain gained per kilogram S applied would be economically attractive. Based on improved agronomic efficiency of fertilizer macronutrients as a result of micronutrient application in deficient soils, Vanlauwe et al. (2015) conclude on blending micronutrients with fertilizers as a cost-effective way to overcome micronutrient deficiency. Since micronutrients are often viewed for their role in human health, and not for their contribution in enhancing crop yields, there are opinions that overcoming soil micronutrients deficiency is a main path to overcoming deficient of those nutrients in human health 


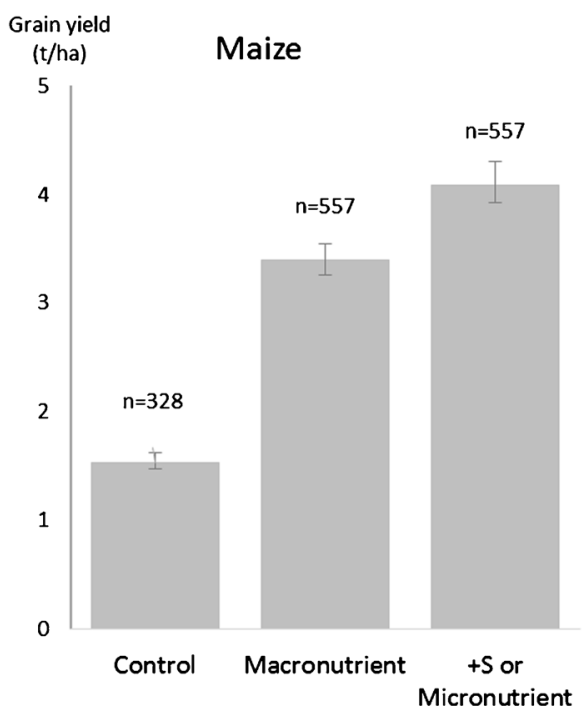

Fig. 6 Grain yield under different fertilizer regimes as observed in the reported studies. Error bars are confidence intervals of the means. For maize, macronutrient treatment had on average $97( \pm 36) \mathrm{kg} \mathrm{N} \mathrm{ha}^{-1}, 34$ $( \pm 20) \mathrm{kg} \mathrm{P} \mathrm{ha}^{-1}$, and $45( \pm 23) \mathrm{kg} \mathrm{K} \mathrm{ha}^{-1}$ applied while $+\mathrm{S}$ or Micronutrient also had $32( \pm 21) \mathrm{S}, 5.6( \pm 3.2) \mathrm{Zn}, 6( \pm 3.5) \mathrm{Fe}, 4.1$ $( \pm 2.7) \mathrm{Cu}$, and $1( \pm 0) \mathrm{B}$. For wheat, macronutrient treatment had on

(Barret and Bevis 2015; de Valenca et al. 2017). As such, the profitability of micronutrient fertilization has been assessed for their role in reducing the health burden associated with micronutrient deficiency in human. Joy et al. (2015) reported that enriching granular fertilizers with $\mathrm{Zn}$ would be cost-effective in reducing healthy life lost due to micronutrient deficiency in human, particularly if embedded into ongoing subsidy programs. The extent to which enrichment of fertilizers could affect

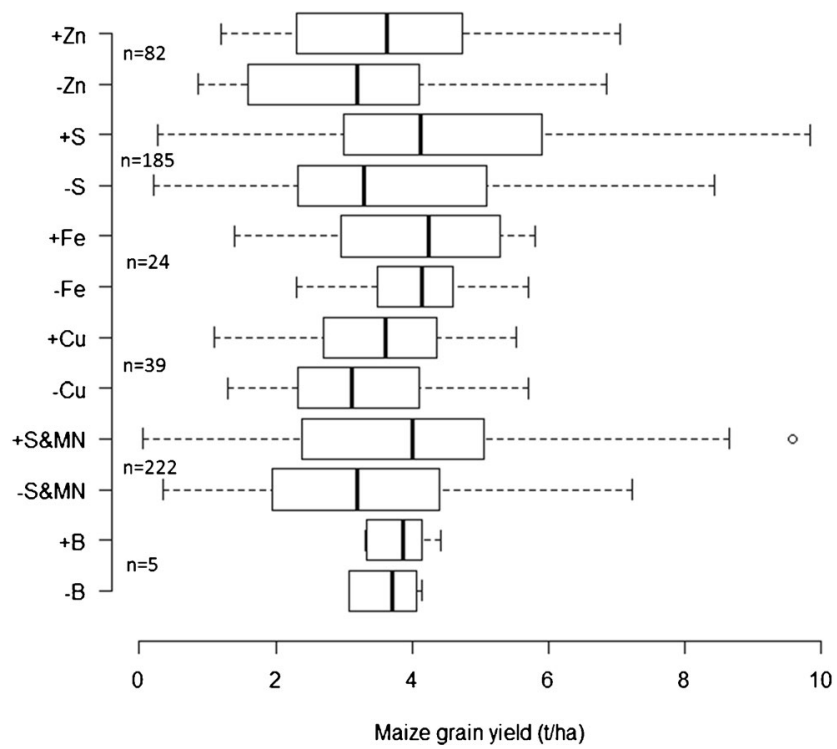

Fig. 7 Boxplots of the effect of S and micronutrient application on yield of maize as observed in SSA. Plus and minus signs indicate if nutrient was added or omitted. $S \& M N$ combined $\mathrm{S}$ and micronutrients
Rice

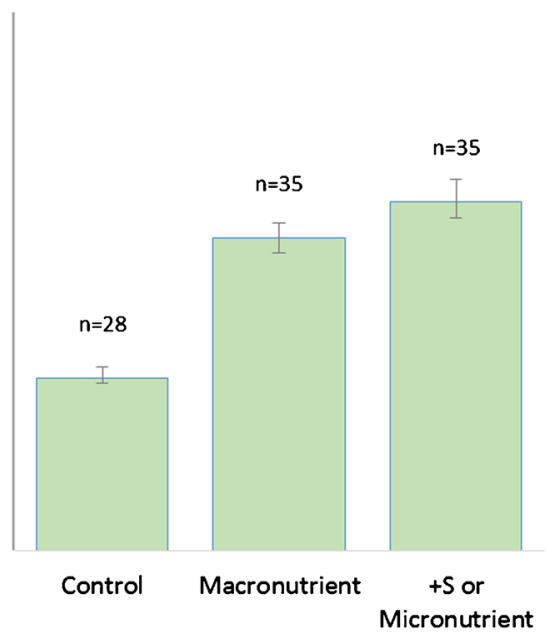

average $91( \pm 67) \mathrm{kg} \mathrm{N} \mathrm{ha}^{-1}, 25( \pm 9) \mathrm{kg} \mathrm{P} \mathrm{ha}^{-1}$, and 36 $( \pm 8.6) \mathrm{kg} \mathrm{K} \mathrm{ha}^{-1}$ applied while $+\mathrm{S}$ or Micronutrient also had $39( \pm 16)$ $\mathrm{S}, 30( \pm 5.7) \mathrm{Zn}$. For rice, macronutrient treatment had on average 66 $( \pm 29) \mathrm{kg} \mathrm{N} \mathrm{ha}^{-1}, 52( \pm 33) \mathrm{kg} \mathrm{P}^{-1}$, and $59( \pm 34) \mathrm{kg} \mathrm{K}^{-1}$ applied while $+\mathrm{S}$ or Micronutrient also had $36( \pm 25) \mathrm{S}, 10( \pm 0) \mathrm{Zn}$. Data used are both from publications and AfSIS

the price of fertilizers is not clear. However, in the context of current efforts of increasing access to fertilizers by farmers, including micronutrient-enriched fertilizers in various subsidy programs has potential to increase widespread application of micronutrients without direct additional costs for farmers covered by such programs.

As expected, maize yield response to macronutrients and to $\mathrm{S}$ and micronutrients significantly varied with soil type (Fig. 9). Average response ratios to $\mathrm{S}$ and micronutrients were positive in all soil types, varying from 0.9 in Luvisols to 2.5 in Gleysols. The lowest yield gains due to $\mathrm{S}$ and micronutrient applications on Luvisols are related to their high inherent fertility. Although yield responses to macronutrients were very low on Gleysols (soils affected/influenced by shallow groundwater) and Vertisols (poor drainage and difficult workability), yield gains due to the addition of micronutrients were high on these soils (Fig. 9b). Trial locations for both soils were characterized by very low soil micronutrients $(<0.26 \mathrm{Cu}$ and 0.23 $\mathrm{Zn} \mathrm{mg} \mathrm{kg}{ }^{-1}$, data not shown). These results indicate the importance of inherent soil properties on crop yields and yield responses to macronutrients, $\mathrm{S}$, and micronutrients, which, in combination with other explaining factors, may provide a good basis for targeting nutrient recommendations.

\subsection{Agronomic efficiency}

As expected, and for all $\mathrm{S}$ and micronutrients, the highest agronomic efficiency (kilograms of maize grain per kilogram of nutrient applied) was observed at low application rates, and decreased with increasing nutrient application. For example, 

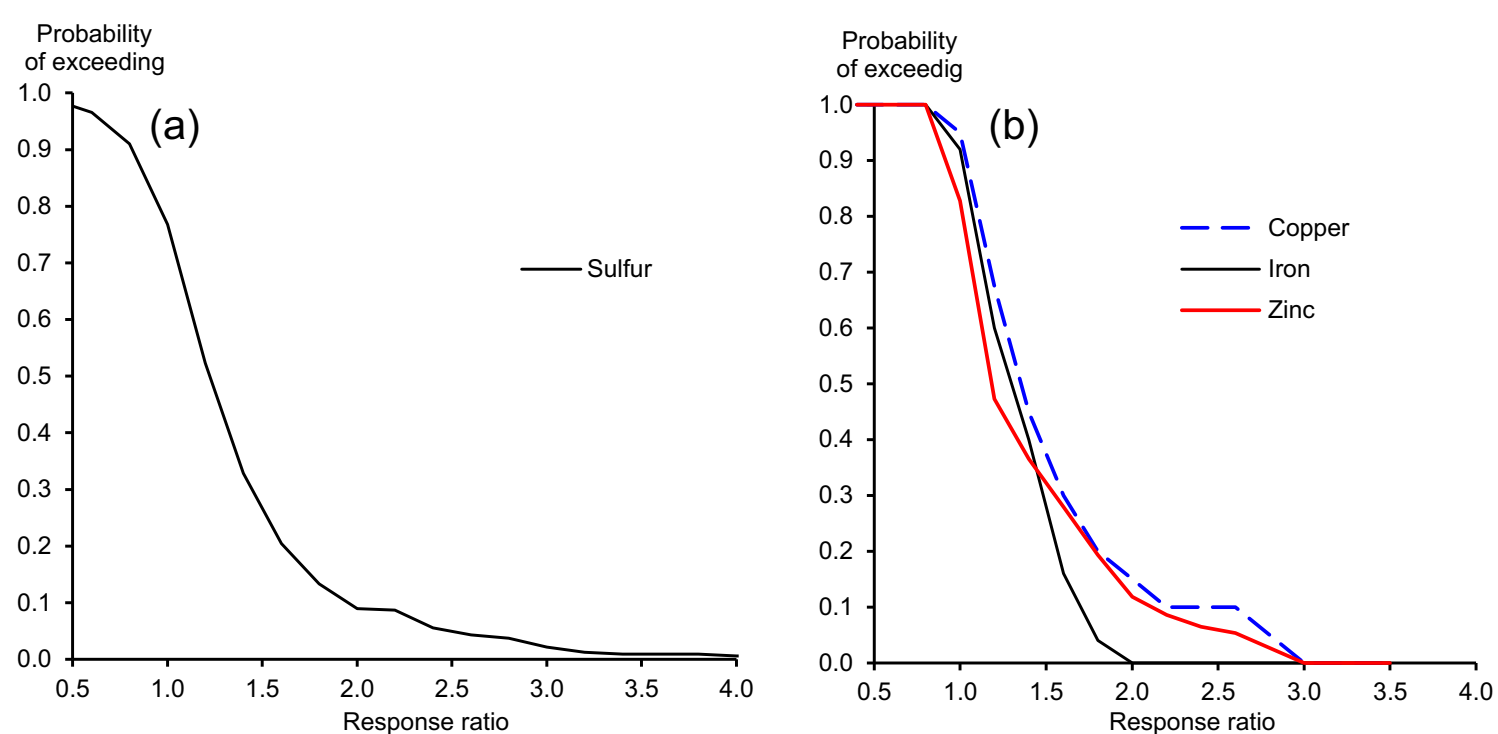

Fig. 8 The probability of exceeding a given response ratios in maize yield following application of (a) sulfur and (b) micronutrients (Cu, $\mathrm{Fe}$, and $\mathrm{Zn}$ )

maximum agronomic efficiency plotted against the amount of S and $\mathrm{Zn}$ applied and defined by the four-parameter dose response function is characterized by decline within the first $30 \mathrm{~kg} \mathrm{~S} \mathrm{ha}^{-1}$ and throughout $\mathrm{Zn}$ application rates (Fig. 10). In other words, application of $\mathrm{S}$ beyond this rate for maize runs the risk of being wasteful. On average, and based on our data, agronomic efficiency of $432 \mathrm{~kg}$ grain kg${ }^{-1} \mathrm{Cu}, 254 \mathrm{~kg}$ grain kg${ }^{-1} \mathrm{Fe}$, $203 \mathrm{~kg}$ grain $\mathrm{kg}^{-1} \mathrm{~B}, 151 \mathrm{~kg}$ grain $\mathrm{kg}^{-1} \mathrm{Zn}$, and $38 \mathrm{~kg}$ grain $\mathrm{kg}^{-1} \mathrm{~S}$ were observed. Further, notable residual effects on crop yield can still be expected in succeeding seasons after application to the soil as observed for $\mathrm{Zn}$ (a 25\% yield increment after 38-75 $\mathrm{kg} \mathrm{Zn} \mathrm{ha}^{-1}$ applied in the previous season) by Soleimani (2012). The highest level of agronomic efficiency followed the application of copper at $0.8 \mathrm{~kg} \mathrm{Cu} \mathrm{ha}^{-1}$ in Nigeria, and is in line with reports of Cu deficiency in eastern Nigerian states (Sillanpaa 1982). Application of micronutrients is known to increase also the use efficiency of the macronutrients (Vanlauwe et al. 2015), and higher macronutrient apparent recoveries have been observed (Girish et al. 2015).

Response to nutrients including micronutrients depends on, among other factors (e.g., soil acidity and interactions between nutrients), the level of crop available nutrients in soil. Excluding AfSIS, only $57 \%$ of the included studies reported micronutrient concentrations in soils. Since methods of soil analysis varied from one study to another, relating soils test values with crop responses was not undertaken in our study.

Studies on crop response to secondary nutrients and micronutrients are scanty in SSA, and research is needed not only to further quantify potential responses under different soils conditions (e.g., $\mathrm{pH}$ and micronutrient levels), crop types, and varieties but also to understand residual effects during subsequent seasons, the effectiveness and use efficiency of different secondary and micronutrient sources, their interactions, and appropriate application methods. This is
Fig. 9 Variation in maize yield (a) and response ratios (b) with soil type. Horizontal bars represent $95 \%$ confidence limits. The vertical bar in (b) represents $\mathrm{RR}=1$ (i.e., no effect of micronutrients)

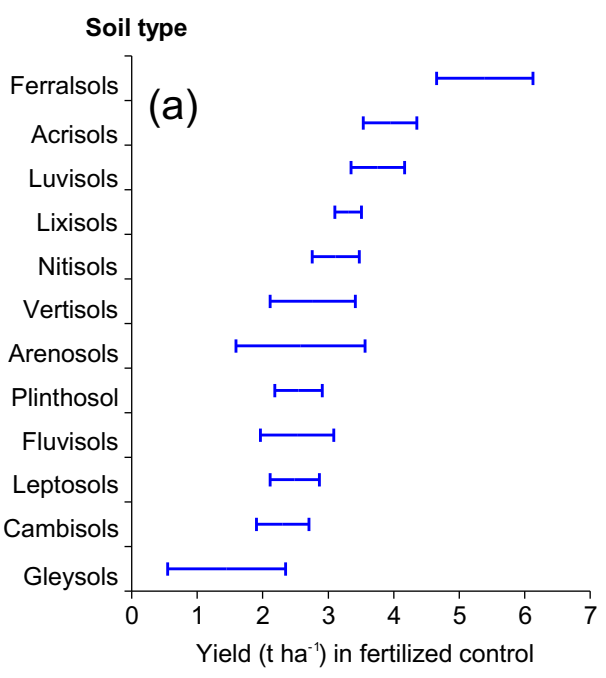

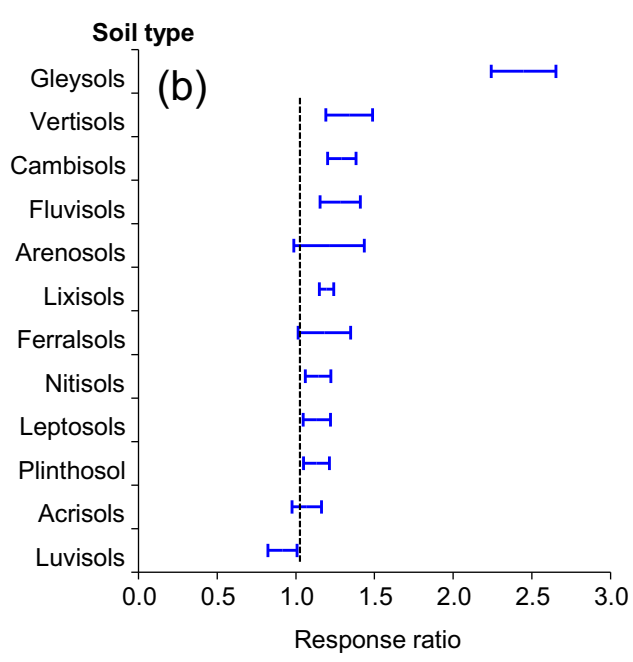


Fig. 10 Boundary lines of agronomic efficiency of sulfur and zinc for maize at different application rates in SSA. Curves are boundary lines of maximum agronomic efficiency

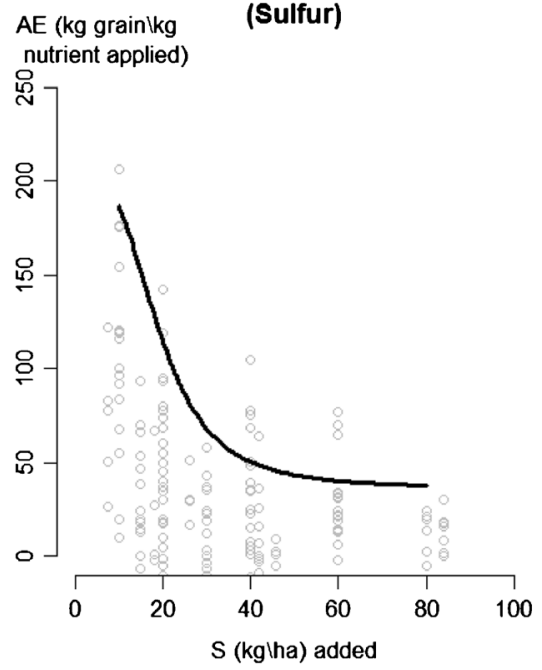

(Zinc)

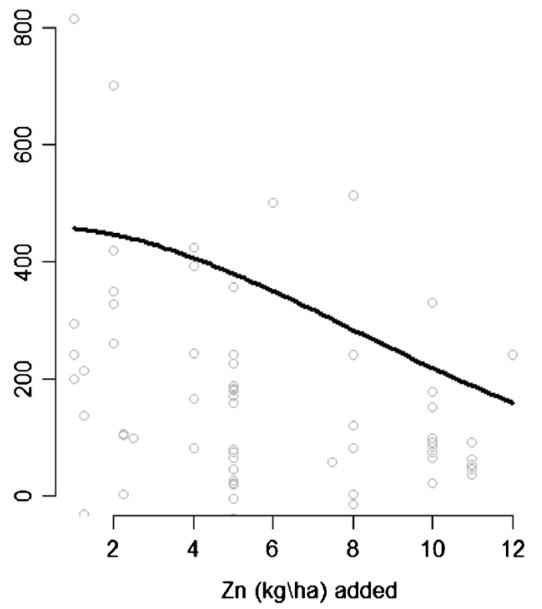

needed in order to ascertain where their applications are required, guide fertilizer blending targeted to the specific production systems, and to recommend best practices to smallholder farmers in SSA. Such research should also go further to relate soil micronutrients or applied $\mathrm{S}$ and micronutrients to nutritional quality of harvest products from different crops and genotypes for human and animal nutrition. Undoubtedly, SSA is in need of micronutrients and more so with the expected increase in crop production level. It is noteworthy that micronutrient fertilizers are not available in all countries or regions where these are needed (see Van Asten et al. (2004)) and efforts are needed by governments to reverse the situation.

\section{Conclusions}

The application of S and micronutrients resulted in $0.84 \mathrm{tha}^{-1}$ more maize yield compared to the recommended $\mathrm{N}, \mathrm{P}$, and $\mathrm{K}$ fertilizers. This represents a $25 \%$ yield increment over what was achieved using the recommended fertilizer, which only contains macronutrients. Although there is high variability in crop response to $\mathrm{S}$ and micronutrients, the high proportions of cases with increased yield underscore the need for these nutrients. $S$ and micronutrients are holding back crop productivity especially on soils where response to macronutrients is low. Coupling the ongoing efforts towards the African green revolution, with the supply of S and micronutrients in most fertilizers, is vital for enhanced agricultural productivity. Considering also the observed incidences of low responses and variations among crops, more research is needed to unravel conditions under which application of $\mathrm{S}$ and micronutrients is beneficial to farmers. The results of this study highlight the need for policy support for the research on secondary nutrients, particularly $\mathrm{S}$, and micronutrients and for blending them in currently used fertilizers. Further, decision support tools and training that can aid uptake of $\mathrm{S}$ and micronutrient technologies by farmers are needed.

Acknowledgements This work was conducted through the support of two projects namely the USAID Feed the Future's Africa RISING Program under the project "transforming key production systems: maize mixed east and southern Africa" and the "sustainable intensification of maize-legume cropping systems for food security in eastern and southern Africa-Phase II (SIMLESA-2)." We acknowledge insights provided by Steve Ichami during formative stages of this publication.

Open Access This article is distributed under the terms of the Creative Commons Attribution 4.0 International License (http:// creativecommons.org/licenses/by/4.0/), which permits unrestricted use, distribution, and reproduction in any medium, provided you give appropriate credit to the original author(s) and the source, provide a link to the Creative Commons license, and indicate if changes were made.

\section{References}

Abbas AE, Medani W, Hamad ME, Medani W, Babiker HM, Medani W, Nour AE (2007) Effects of added phosphorus and zinc on yield and its components of corn. Gezira J Agric Sci 5(2)

Abe SS, Buri MM, Issaka RN, Kiepe P, Wakatsuki T (2010) Soil fertility potential for rice production in West African lowlands. Jpn Agric Res q 44:343-355

Abunyewa AA, Mercer-Quarshie H (2004) Response of maize to magnesium and zinc application in the semi-arid zone of West Africa. Asian J Plant Sci 3(1):1-5

Adeboye MKA (2011) Status of total and available boron and zinc in the soils of Gongola river basin of Nigeria. Savannah J Agric 6:47-57

Adesoji AG, Abubakar IU, Ishaya DB (2009) Performance of soybean (Glycine max(L.) Merrill) as influenced by method and rate of molybdenum application in Samaru, northern Guinea Savanna of Nigeria. Am-Eurasian J Sustain Agric 3(4):845-849

Admas H, Gebrekidan H, Bedadi B, Adgo E (2015) Effects of Organic and Inorganic Fertilizers on Yield and Yield Components of Maize at Wujiraba Watershed, Northwestern Highlands of Ethiopia. American J. Plant Nutr and Fert Tech 5:1-5

Afolabi SG, Adekanmbi AA, Adeboye MK, Bala A (2014) Effect of various input combinations on the growth, nodulation and yield of 
inoculated soybean in Minna. Nigeria Int J Agric Rural Dev 17(3): 2006-2011

Allan AY (1971) Fertilizer use on maize in Kenya. In FAO. Improving Soil Fertility in Africa. FAO Soils Bulletin 14. Rome, Italy. pg 10-25.

Barret CB, Bevis LEM (2015) The micronutrient deficiencies challenge in African food system. In: Sahn DE The fight against hunger and malnutrition: the role of food, agriculture and targeted policies. Oxford University Press, 61-84

Buri MM, Masunaga T, Wakatsuki T (2000) Sulfur and zinc levels as limiting factors to rice production in West Africa lowlands. Geoderma 94:23-42. doi:10.1016/S0016-7061(99)00076-2

Chaguala PA, Nobela L, Aline S, Maria R, Buque I (2011) Maize response to macro-and micro-nutrients in two different agro-ecological zones in Mozambique. In 10th African Crop Science Conference Proceedings, Maputo, Mozambique (10-13 October 2011). Afr Crop Sci Soc.

Chianu JN, Chianu JN, Mairura F (2012) Mineral fertilizer in the farming systems of sub-Saharan Africa. A review. Agron Sustain Dev 32: 545-566. doi:10.1007/s13593-011-0050-0

Chiezey UF (2014) Field Performance of Quality Protein Maize with Zinc and Magnesium Fertilizers in the Sub-Humid Savanna of Nigeria. J Agric Sci 6(3):84

Chilimba ADC, Chirwa IMD (2000) Sulphur nutrient deficiency amendment for maize production in Malawi. Report for Chitedze Research Station. Ministry of Agriculture, Lilongwe

Chude VO, Iwuafor ENO, Amapu IY, Pam SG, Yusuf AA (2003) Response of maize to zinc fertilization in relation to Mehlich III extractable zinc. In Badu-Apraku B, Fakorede MAB, Ouedraogo M, Carsky RJ, Menkir A (eds) Maize revolution in West and Central Africa, p 201-207.

Desta HA (2015) Response of maize (Zea mays L.) to different levels of nitrogen and sulfur fertilizers in Chilga district, Amhara national regional state, Ethiopia. Int J Recent Sci Res 6:5689-5698

Desta Y, Habtegebrial K, Weldu Y (2015) Inoculation, phosphorous and zinc fertilization effects on nodulation, yield and nutrient uptake of Faba bean (Vicia faba L.) grown on calcaric cambisol of semiarid Ethiopia. J Soil Sci Env Mgt 6(1):9-15

De Valenca AW, Bake A, Brouwer ID, Giller KE (2017) Agronomic biofertilization of crops to fight hidden hunger in sub-Saharan Africa. Gobal Food Sec 12:8-14

Drosdoff M (1972) Soil micronutrients. In: Soils of the humid tropics. National Academy of Sciences, Washington, D.C., pp 150-162

Eteng EU, Asawalam DO, Ano AO (2014) Effect of Cu and Zn on Maize (Zea mays L.) Yield and Nutrient Uptake in Coastal Plain Sand Derived Soils of Southeastern Nigeria. Open J Soil Sci 4:235-245

Florent Z, Kone B, Jeremie GT, Fulgence AE, Firmin KK, Joachim TM, N'ganzoua KR, Albert YK (2014) Lowland Rice Yield as Affected by Straw Incorporation and Inorganic Fertilizer Over Cropping Seasons in Fluvisol. J Adv Agri 3(1):129-141

Friesen DK (1991) Fate and efficiency of sulfur fertilizer applied to food crops in West Africa. Fert Res 29(1):35-44

Girish C, Suhas PW, Kanwar LS, Rajesh C (2015) Enhanced nutrient and rainwater use efficiency in maize and soybean with secondary and micro nutrient amendments in the rainfed semi-arid tropics. Arch Agron Soil Sci 61(3):285-298. doi:10.1080/03650340.2014. 928928

Gungula DT, Garjila Y (2006) The effects of molybdenum application on growth and yield of cowpea in Yola. J Agric Environ Sci 1(2):96101

Gurevitch J, Hedges LV (1999) Statistical issues in ecological meta-analyses. Ecology 80(4):1142-1149

Habtegebrial K, Singh BR (2006) Effects of timing of nitrogen and sulphur fertilizers on yield, nitrogen, and sulphur contents of Tef (Eragrostis tef (Zucc.) Trotter). Nutr Cycl Agroecosyst 75:213-222
Habtegebrial K, Singh BR (2009) Response of wheat cultivars to nitrogen and sulfur for crop yield, nitrogen use efficiency and protein quality in the semiarid region. J. Plant Nutr 32:1768-1787

Habtegebrial HK, Ram SB, Aune JB (2007) Wheat response to N2 fixed by faba bean (Vicia faba L.) as affected by sulfur fertilization and rhizobial inoculation in semi-arid Northern Ethiopia. J Plant Nutr Soil Sci 170(3):412-418

Habtegebrial K, Mersha S, Habtu S (2013) Nitrogen and sulphur fertilizers effects on yield, nitrogen uptake and nitrogen use efficiency of upland rice variety on irrigated Fluvisols of the Afar region, Ethiopia. J Soil Sci Env Mgt 4:62-70

Haileselassie B, Stomph TJ, Hoffland E (2011) Teff (Eragrostis tef) production constraints on Vertisols in Ethiopia: farmers' perceptions and evaluation of low soil zinc as yield-limiting factor. Soil Sci Plant Nutr 57:587-596

Hedges LV, Gurevitch J, Curtis PS (1999) The meta-analysis of response ratios in experimental ecology. Ecology 80:1150-1156

Hossard L, Archer DW, Bertrand M, Colnenne-David C, Debaeke P, Ernfors M, Jeuffroy M, Munier-Jolain N, Nilsson C, Sanford GR, Snapp SS, Jensen ES, Makowski D (2016) A meta-analysis of maize and wheat yields in low-input vs. conventional and organic systems. Agron J 108:1155-1167. doi:10.2134/agronj2015.0512

Huising J, Zingore S, Kihara J, Nziguheba G (2013) Diagnostic trials: a practical guide and instruction manual. African Soil Information Service, Nairobi, $53 \mathrm{p}$

Joy EJM, Stein AJ, Young SD, Ander EL, Watts MJ, Broadley MR (2015) Zinc-enriched fertilisers as a potential public health intervention in Africa. Plant Soil 389:1-24

Kang BT, Osiname OA (1976) Sulfur response of maize in Western Nigeria. Agron J 68:333-336

Kang BT, Osiname OA (1985) Micronutrient problems in tropical Africa. Fertil res 7(1-3):131-150

Kayode GO (1984) Effect of iron on maize yields in forest and Savanna zones of Nigeria. Exp Agric 20:335-337

Kayode GO, Agboola AA (1985) Macro and micro-nutrient effects on the yield and nutrient concentration of maize (Zea mays L.) in South Western Nigeria. Nutr Cycl Agroecosyst 8(2):129-135

Kihara J, Njoroge S (2013) Phosphorus agronomic efficiency in maizebased cropping systems: a focus on western Kenya. Field crops Res 150:1-8. doi:10.1016/j.fcr.2013.05.025

Kihara J, Nziguheba G, Zingore S, Coulibaly A, Esilaba A, Kabambe V, Njoroge S, Palm C, Huising J (2016) Understanding variability in crop response to fertilizer and amendments in sub-Saharan Africa. Agric Ecosyst Environ 229:1-12. doi:10.1016/j.agee.2016.05.012

Koné B, Amadji GL, Aliou S, Diatta S, Akakpo C (2011) Nutrient constraint and yield potential of rice on upland soil in the south of the Dahoumey gap of West Africa. Arch Agron Soil Sci 57(7):763-774

Kone B, Fofana M, Sorho F, Diatta S, Ogunbayo A, Sie M (2014) Nutrient constraint of rainfed rice production in foot slope soil of Guinea Forest in Côte d'Ivoire. Arch Agron Soil Sci 60(6):735-746

Kurwakumire N, Chikowo R, Zingore S, Mtambanengwe F, Mapfumo P, Snapp S, Johnston A (2015) Nutrient Management Strategies on Heterogeneously Fertile Granitic-Derived Soils in Subhumid Zimbabwe. Agron J 107(3):1068-1076

Ladha JK, Pathak H, Krupnik TJ, Six J, van Kessel C (2005) Efficiency of fertilizer nitrogen in cereal production: retrospects and prospects. Adv Agron 87:85-156. doi:10.1016/S0065-2113(05)87003-8

Leonardo WJ, van de Ven GWJ, Udo H, Kanellopoulos A, Sitoe A, Giller KE (2015) Labour not land constrains agricultural production and food self-sufficiency in maize-based smallholder farming systems in Mozambique. Food Sec 7:857-874. doi:10.1007/s12571-015-0480-7

Lisuma JB, Semoka JM, Semu E (2006) Maize yield response and nutrient uptake after micronutrient application on a volcanic soil. Agron J 98(2):402-406

Lopes AS (1980) Micronutrients in soils of the tropics as constraints to food production. In: Drosdoff M, Zandstra H, Rockwood WG (eds) 
Priorities for alleviating soil-related constraints to food production in the tropics. International Rice Research Institute, Los Banos, pp 277-298

Manzeke GM, Mtambanengwe F, Nezomba H, Mapfumo P (2014) Zinc fertilization influence on maize productivity and grain nutritional quality under integrated soil fertility management in Zimbabwe. Field Crop Res 166:128-136

Ndakidemi PA, Semoka JMR (2006) Soil fertility survey in western Usambara Mountains, northern Tanzania. Pedosphere 16(2):237244. doi:10.1016/S1002-0160(06)60049-0

Nesgea S, Gebrekidan H, Sharma JJ, Berhe T (2012) Effects of nitrogen sources and application time on yield attributes, yield and grain protein of rain-fed NERICA-3 rice in Gambella, Ethiopia. Int J Agro Agri Res 2(9):14-32

Nyalemegbe KK, Hotsonyame GK, Ofori F, Osakpa TY (2012) Comparative study of the efficacy of actyva compound fertilizer (N23 P10 K5 3S 2MgO 0.3 Zn) on maize cultivation in the coastal savanna and the humid forest ecologies of Ghana. Int Res J Agric Sci Soil Sci 2(1):8-16

Nziguheba G, Tossah BK, Diels J, Franke AC, Aihou K, Iwuafor EN, Nwoke C, Merckx R (. (2009) Assessment of nutrient deficiencies in maize in nutrient omission trials and long-term field experiments in the West African Savanna. Plant Soil 314(1-2):143

Ojeniyi SO, Kayode GO (1993) Response of maize to copper and sulfur in tropical regions. J Agric Sci 120:295-299. doi:10.1017/ S0021859600076450

Olivier K, Cherif M, Kone B, Emmanuel D, Firmin KK (2014) Growth, yields and ratooning performance of lowland rice Nerica 114 as affected by different fertilizers. Ind J Sci Res Tech 2(2):18-24

Oseni TO (2009) Growth and zinc uptake of sorghum and cowpea in response to phosphorus and zinc fertilization. World J Agric Sci 5(6):670-674

Osiname OA, Kang BT, Schulte EE, Corey RB (1973) Zinc response of maize (Zea mays L.) grown on sandy Inceptisols in western Nigeria. Agron J 65(6):875-877

Oyinlola EY, Chude VO (2010) Status of available micronutrients of the basement Complex rock-derived Alfisols in northern Nigeria Savanna. Trop Subtrop Agroecosyst 12:229-237

Philibert A, Loyce C, Makowski D (2012) Assessment of the quality of meta-analysis in agronomy. Agric Ecosyst Environ 148:72-82. doi: 10.1016/j.agee.2011.12.003

Rechiatu A, Ewusi-Mensah N, Abaidoo RC (2015) Response of Soybean (Glycine $\max$ L.) to Rhizobia Inoculation and Molybdenum Application in the Northern Savannah Zones of Ghana. J Plant Sci 3(2):64-70. doi:10.11648/j.jps.20150302.14

Ryan J, Rashid A, Torrent J, Kwong YS, Ibrikci H, Sommer R, Bulent EE (2013) Micronutrient constraints to crop production in the Middle East-west Asia region: significance, research, and management. Adv Agron 122:1-84. doi:10.1016/b978-0-12-417187-9.00001-2

Sahrawat KL, Wani SP, Pardhasaradhi G, Murthy KVS (2010) Diagnosis of secondary and micronutrient deficiencies and their management in rainfed agroecosystems: case study from Indian semi-arid tropics. Commun Soil Sci Plant Anal 41:346-360. doi:10.1080 00103620903462340

Sileshi G, Akinnifesi FK, Debusho LK, Beedy T, Ajayi OC, Mong'omba S (2010) Variation in maize yield gaps with plant nutrient inputs, soil type and climate across sub-Saharan Africa. Field Crops Res 116:113. doi:10.1016/j.fcr.2009.11.014

Sillanpaa M (1982) Micronutrients and the nutrient status of soils: a global study, Issue 48. FAO, Rome

Snapp SS (1998) Soil nutrient status of smallholder farms in Malawi. Commun Soil Sci Plant Anal 29:2571-2588. doi:10.1080/ 00103629809370135

Soleimani R (2012) Cumulative and residual effects of zinc sulfate on grain yield, zinc, iron, and copper concentration in corn and wheat. J Plant Nutr 35:85-92. doi:10.1080/01904167.2012.631669

Stoorvogel JJ, Smaling EMA, Hanssen BH (1993) Calculating soil nutrient balances in Africa at different scales. Fert Res 35:227-285. doi: 10.1007/BF00750641

Tittonnell P, Giller KE (2013) When yield gaps are poverty traps: the paradigm of ecological intensification in African smallholder agriculture. Field Crops Res 143:76-90. doi:10.1016/j.fcr.2012.10.007

Van Asten PJA, Barro SE, Wopereis MCS, Defoer T (2004) Using farmer knowledge to combat low productive spots in rice fields of a Sahelian irrigation scheme. Land degrad Develop 15:383-396. doi:10.1002/ldr.619

Vanlauwe B, Kihara J, Chivenge P, Pypers P, Coe R, Six J (2011) Agronomic use efficiency of $\mathrm{N}$ fertilizer in maize-based systems in sub-Saharan Africa within the context of integrated soil fertility management. Plant Soil 339:35-50. doi:10.1007/s11104-0100462-7

Vanlauwe B, Descheemaeker K, Giller KE, Huising J, Merckx R, Nziguheba G, Wendt J, Zingore S (2015) Integrated soil fertility management in sub-Saharan Africa: unravelling local adaptation. Soil 1:491-508. doi:10.5194/soil-1-491-2015

Voortman RL (2012) Micronutrients in agriculture and the world food system - future scarcity and implications. In: Scarcity of micronutrients in soil, food and mineral resources - background report of the platform Agriculture, innovation and society (LIS)

Weil RR, Mughogho SK (1999) Sulfur nutrition of maize in four regions of Malawi. Agron J 92(4):649-656. doi:10.2134/agronj2000. 924649x

Wopereis CSM, Diagne A, Johnson DE, Seck PA (2013) Realizing Africa's rice promise: priorities for action. In: Wopereis CSM, Johnson DE, Nourollah A, Tollens E, Jalloh A (eds) Realizing Africa's rice promise. CAB International. CPI Group (UK) Ltd, Croydon, pp 424-436

Yerokun OA, Chirwa M (2014) Soil and foliar application of Zinc to maize and wheat grown on a Zambian Alfisol. Afr J Agric Res 9(11):963-970 